\section{A LINGUISTIC LANDSCAPE STUDY OF SIGNAGE ON NIMMANHEMIN ROAD, A LANNA CHIANG MAI CHILL-OUT STREET}

\section{Tiwahporn Thongtong ${ }^{1}$}

\begin{abstract}
This study investigates how the linguistic landscape both creates and reflects a tourist space on language choices in creating signs on Nimmanhemin Road in Chiang Mai, Thailand. In addition, the study explores what linguistic devices are used in the creation of signs on Nimmanhemin Road. Sign data are collected from both sides of Nimanhaemin Road. Every sign in front of stores was photographed and analyzed in terms of language choices and linguistic devices. The study reveals that tourism in Chiang Mai has influences on language choices in sign creation. Monolingual, bilingual and trilingual signs can be found on Nimmanhemin Road, normally written in Thai, English and / or Chinese. In terms of linguistic strategies, transliteration, word formation, lexical relations, speech acts and politeness strategies are demonstrated in my findings. The study has both theoretical and practical contributions. Theoretically, it challenges commonly held notions of bilingual organization of information and language prominence.
\end{abstract}

\footnotetext{
${ }^{1}$ a Ph.D. candidate in English as an International Language Program from Chulalongkorn University. She graduated with a Master's degree in Language and Culture for Communication and Development from Mahidol University and received her Bachelor's degree in Education from Chiang Mai University.
}

Practically, the study has pedagogical applications and the study findings can be used for English language instruction.

\section{Introduction}

Linguistic landscape studies can be seen as a sub-field of both sociolinguistics and applied linguistics, concerned with the "written form" of languages in public space (Gorter and Cenoz 2006, p. 2) especially focusing on "multilingual settings" (Coulmas 2009, p. 14). According to Landry and Bourhis (1997, p. 25), linguistic landscape refers to "The language of public road signs, advertising billboards, street names, place names, commercial shop signs, and public signs on government buildings ... of a given territory, region, or urban agglomeration". But the field of linguistic landscape studies has expanded from the analysis of commercial and government signs found on the streets of large metropolitan centers, ethnic neighborhoods and small towns. Among the diverse objects of linguistic landscape scrutiny are schools (Dagenais et al 2009; Dressler 2015), train stations (Lock 2003; Backhaus 2006), science labs (Hanauer 2009); apartment buildings (Jaworski and Yeung 2010), post cards (Jaworski 2010), public monuments (Shohamy and Waksman 2009; Abousnnouga and Machin 2010), and cyberspace (Ivkovic and Lotherington 2009; Troyer 2012; Jones 2011). Linguistic landscapes have been investigated from a number of viewpoints, such as language policy and language ideology (Sloboda 2009; Marten 2010), national and ethnic identity (TrumperHecht 2009; Dray 2010) language awareness and education (Dagenais et al., 2009), marginalization of minority communities (Lou 2010), language switching and hybridization (Huebner 
2009), linguistic input for language learning (Cenos \& Gorter 2008; Dagenais et al 2009; Bolton 2012; Sayer 2010), and tourism and the commodification of culture (Kallen 2009; Piller 2010; Moriarty 2015).

Tourist spaces are complex sites of language contact. Indeed the creation of tourist spaces relies heavily on the linguistic landscapes of those spaces (Bruyei- Olmedo and Juan-Garau 2009; Jaworski 2010; Moriarty 2015). Language usage for tourism promotion is an essential source of information for the potential tourists. It engages people in decisionmaking regarding the destination they would like to travel to (Salim et al 2012). Research on language and tourism is in its infancy in both linguistics and tourism studies. Much of the research comes from within sociolinguistics, where scholars have considered how the particular social context of the tourist encounter reflects or challenges existing theories of language use (Cohen and Cooper 1986; Heller 2003; Boudreau and White 2004; Manca 2008; Jaworski 2010). Other related work in sociolinguistics considers the role of language in the broader representation of cultural perspectives, and other identities in tourism destinations (Pietikäinen and Kelly-Holmes 2001; Coupland et al 2005; Cos 2006; Drozdzewski 2011; Thurlow and Jaworski 2011; Strand 2012, 2013; Ploner 2013). Studies of linguistic landscape and tourism have contributed to an understanding of how language and tourism are related and how cultural perspectives and other identities in tourism destinations are presented in tourist space.

While there have been few studies of the linguistic landscapes of Thailand, and only one to my knowledge, of linguistic landscapes outside of Bangkok (Draper
2010), none has looked at the role of the linguistic landscape in the creation and promotion of tourist spaces in Thailand. To bridge the gap, this study investigates signage on Nimmanhemin Road, an upscale tourist street in Chiang Mai, Thailand's second city, the metropolitan hub and major tourist attraction of Northern Thailand, and the former capital of the ancient Lanna Kingdom.

\section{The Context and Research Questions}

One of the most attractive tourist destinations in the north of Thailand, the city of Chiang Mai has a rich, idealized and romanticized history. Chiang Mai and its surroundings are blessed with stunning natural beauty and a uniquely indigenous cultural identity. Chiang Mai has had a long and mostly independent history, which has to a large extent preserved a most distinctive culture. This is witnessed both in the daily lives of the people, who maintain their own dialect, customs and cuisine, and in a host of ancient temples, fascinating for their northern Thai architectural styles and rich decorative details. Chiang Mai also continues its renowned tradition as a handicraft center, producing items in silk, wood, silver, ceramics, umbrellas, textiles and more, which make the city the country's top shopping destination for arts and crafts.

There are many languages spoken in Northern Thailand. The distinctive northern dialect is a major regional dialect and may be considered a high prestige dialect of Thai. Eighty percent of the people in Chiang Mai are locals by birth and speak Northern Thai dialect, also known as Chiang Mai dialect or Kam Mueang, which varies from Standard Thai, the official language in its phonology and 
lexicon (Leerabhandh Hatfield, 2005, p.11-12). Northern Thai also varies considerably within northern Thailand itself. Other minority languages in the North include related languages of the TaiKadai language family (e.g., Tai Dam, Tai Lue, etc.) and various unrelated languages spoken by minority hill tribe communities. Due to the promotion of northern tourism, other languages including English and Chinese are also used in tourist areas to communicate with foreign tourists.

Nimmanhemin Street, a famous tourist destination within Chiang Mai is often called a 'chill-out street'. It has been selected for this study because of it is location at the center of the city and because of the transformation it has undergone in the past generation. Originally one of the very first areas of Chiang Mai set aside specifically for residential use, in the past, the Nimman area was nothing more than a neighborhood of houses, old apartment complexes and noodle shops. Because of its proximity to Chiang Mai University (CMU), medical centers, Chiang Mai International Airport, the Convention Hall of CMU, and the CMU Art \& Cultures Center, it became home to a number of university teachers, doctors and government officers who moved there some 40 to 50 years ago. Its location in the town's center with links to many main roads such as Superhighway Road, Chiang Mai - Lampang Road, Huaykaew Road, Suthep Road, and Irrigation Canal Road, has brought many entrepreneurs and their businesses which have transformed the Nimmanhemin area into a popular commercial area catering to the Chiang Mai tourist trade. A revitalization of the area left it bursting at the seams with trendy cafes, casual and high-end restaurants, art galleries, stylish boutiques, coffee shops, tea houses, wine bars, sushi joints and craft shops. As one walks through Nimmanhemin's alleys, one can see some beautiful houses among the shops. Most of those houses are modernstyle houses influenced by the western modern architectural movement popular in Thailand since the 1970's (Ward 2012). Hints of the neighborhood's history remain, creating a mix of authentic Thai architecture and quirky new commercial development. That mix makes Nimmanhemin Road one of the popular tourist destinations with visitors from various countries.

It can be noticed that signage on Nimmanhemin Road is written in many languages and displays a creativity not found in more traditional Thai neighborhoods. Therefore, this study investigates both the choice of language(s) and the linguistic devices used in the signage on Nimmanhemin Road to create the tourist space it has become. Specific research questions are:

1. To what extent does the linguistic landscape both create and reflect Nimmanhaemmin Road as a tourist space?

2. What specific linguistic strategies are used to create signs on Nimmanhemin road?

\section{Analytical frame and Methodology}

This study is a mixed method study. The quantitative study involves the classification of signs collected according to the types of businesses represented and the languages found. In the case of multilingual signs, the study applies Reh's notion of bilingual distribution of information across languages, and Kress and Van Leeuwan's grammar of space to 
determine the relative prominence of each language. The qualitative aspect of the study investigates the types of linguistic, literary and rhetorical devices or strategies that help create and define a tourist space.

Data were collected on Nimmanhemin Road starting from Rincome intersection on Huay Kaew Road to Chiang Mai University Convention Center. Signs located in small alleys off Nimmanhemin Road were not included in this study. The investigation of signage on Nimmanhemin Road focused on only its main street, which is approximately 800 meters long. All signs in front of every single store on both sides of the main street of Nimmanhemin road were photographed on October 10, 2015. Signage from stores that were closed or renovated were not chosen for the analysis. There were altogether 321 signs used for the analysis in terms of language choices and linguistic devices.

\section{Findings}

In this section, findings will be presented to answer the two research questions. To answer the first research question, to what extent the linguistic landscape both creates and reflects Nimmanhaemmin Road as a tourist space, the study results can be explained in terms of sign categorizations and language choices. Signs collected in this study demonstrate presentations of monolingual, bilingual and trilingual signs. With respect to bi- and multilingual signs, physical relationship between sign and audience and individual inference based on lived experiences, rather than strict application of Rey's bilingual information types or Kress and Van Leeuwen's grammar of space, determine the type and amount of information available through a given language. In answer to the second research question, linguistic, literary and rhetorical devices found in the signage include transliteration, lexical blends, hybrid structures, acronyms, homophones, personifications, speech acts, and politeness strategies.

\subsection{Sign Categorizations}

That Nimmanhaemmin Road as a tourist space can be confirmed by the number and nature of shop signs targeted at tourists. The table shown below indicates that most signs are spa and massage signs $(23 \%)$. Others are textile, crafts and souvenir shop signs $(17 \%)$, travel agency signs $(15 \%)$, coffee shop signs $(13 \%)$, restaurant signs $(9 \%)$, hair salon signs $(6 \%)$, clinic signs (5\%), bank signs $(5 \%)$, company signs $(3 \%)$, school signs (2\%) and wedding studio signs $(2 \%)$. Clearly the majority of businesses such as spa and massage centers and travel agencies are aimed at tourists.

\begin{tabular}{|l|c|}
\hline \multicolumn{1}{|c|}{ Type of Signs } & Percentage \\
\hline $\begin{array}{l}\text { Spa and massage center } \\
\text { signs }\end{array}$ & 23 \\
\hline $\begin{array}{l}\text { Textile, crafts and } \\
\text { souvenir shop signs }\end{array}$ & 17 \\
\hline Travel agency signs & 15 \\
\hline Coffee shop signs & 13 \\
\hline Restaurant signs & 9 \\
\hline Hair salon signs & 6 \\
\hline Clinic signs & 5 \\
\hline Bank signs & 5 \\
\hline Company signs & 3 \\
\hline School signs. & 2 \\
\hline Wedding studio signs & 2 \\
\hline
\end{tabular}

Table 1: Type of Signs

\subsection{Language Choices}

One way the linguistic landscape both creates and reflects Nimmanhaemmin Road 


\begin{tabular}{|l|l|l|}
\hline \multicolumn{1}{|c|}{ Monolingual Signs } & \multicolumn{1}{c|}{ Bilingual Signs } & \multicolumn{1}{c|}{ Multilingual Signs } \\
\hline $\begin{array}{l}\text { (1) English (45\%) } \\
\text { (2) Thai (30\%) } \\
\text { (3) Chinese (25\%) }\end{array}$ & $\begin{array}{l}\text { (1) English - Chinese (54\%) } \\
\text { (2) Thai - Chinese (26\%) }\end{array}$ & $\begin{array}{l}\text { (1) Thai - English - Chinese (98\%) } \\
\text { (3) Thai - English (20\%) }\end{array}$ \\
\hline
\end{tabular}

Table 2: Language Choices

as a tourist space is language choices used in creating signs. Monolingual, bilingual and multilingual signs were used to attract foreigners from other countries to visit Nimmanhemin Road.

In this section, signs are classified according to language choices used. Language choices found in signage on Nimmanhemin Road are represented in Table 2.

With respect to the given table, it can be seen that English (45\%) is a dominant language for monolingual signs while Thai $(30 \%)$ and Chinese $(25 \%)$ tend to be less frequently used. However, Chinese and English (54\%) seem to be more frequently chosen for bilingual signs than Thai Chinese (26\%) or Thai - English (20\%). English is used in all trilingual signs; Thai - English - Chinese (98\%) combinations far outnumber the only other trilingual combination, Thai - English - Korean (2\%). From a purely quantitative perspective, English would be considered the dominant language of the commercial shop signs, though Chinese is also ubiquitous. The next section will take a closer look at monolingual, bilingual and trilingual signs.

Monolingual signs used to promote shops on Nimmanhemin Road seem to indicate certain purposes. To illustrate, as shown in picture 1, a seafood buffet restaurant of spicy hot pot shows the logo in circle representing a Chinese character used for celebration of marriage. The sign is a symbol for good luck, fortune and celebration of some festivals which may arouse good feelings for people. The Chinese monolingual sign is targeted at Chinese tourists since most non-Chinese including Thais cannot read Chinese. Signs written in Thai are likely to serve two functions: first, to convey a concept of Thainess to non-Thai tourists; and second, to make local people understand what kinds of products are sold in the shop. English monolingual signs also serve multiple purposes: to inform nonThai, non-Chinese readers of the goods and services available, and often to make products look more expensive and extraordinary. In each case, the choice of language has economic motivations and consequences.

Applied to trilingual signs, this taxonomy becomes a bit problematic. As shown in picture 2, a convenience store on Nimmanhemin Road displays the ThaiEnglish-Chinese trilingual sign "Chiang Mai Hot" to attract foreign customers. Like many multilingual signs, it can be analyzed as employing a combination of fragmentary and complementary strategies. In the example, both Thai and English scripts display "Chiang Mai Hot" 


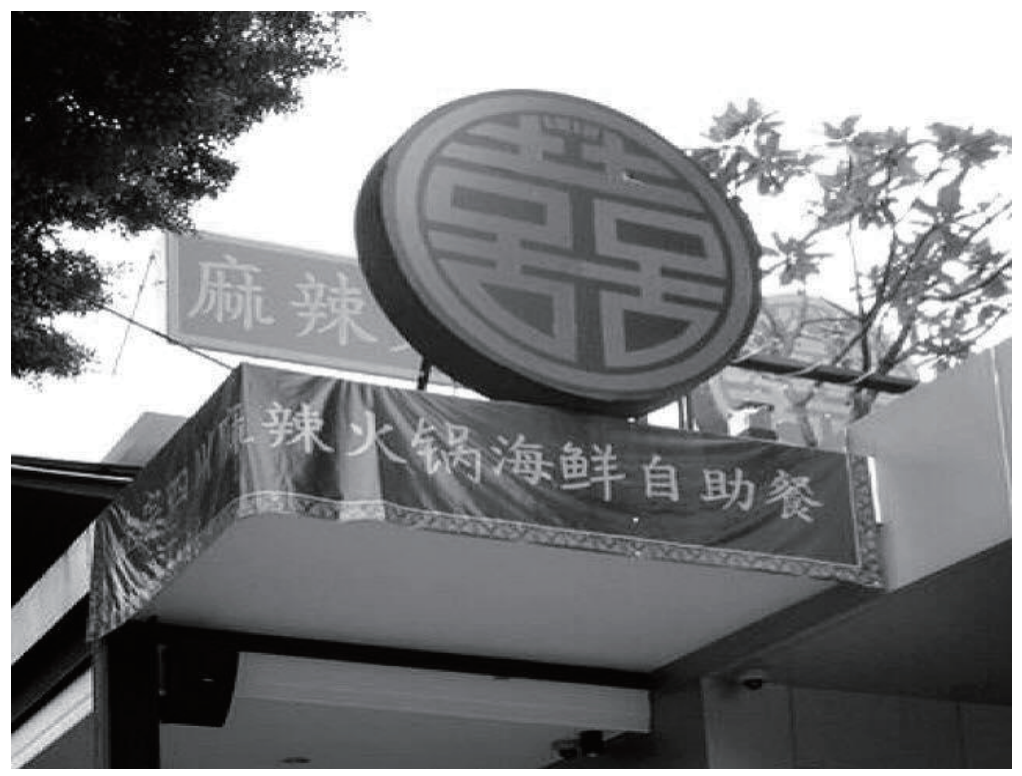

Picture 1: A Monolingual Sign in Chinese

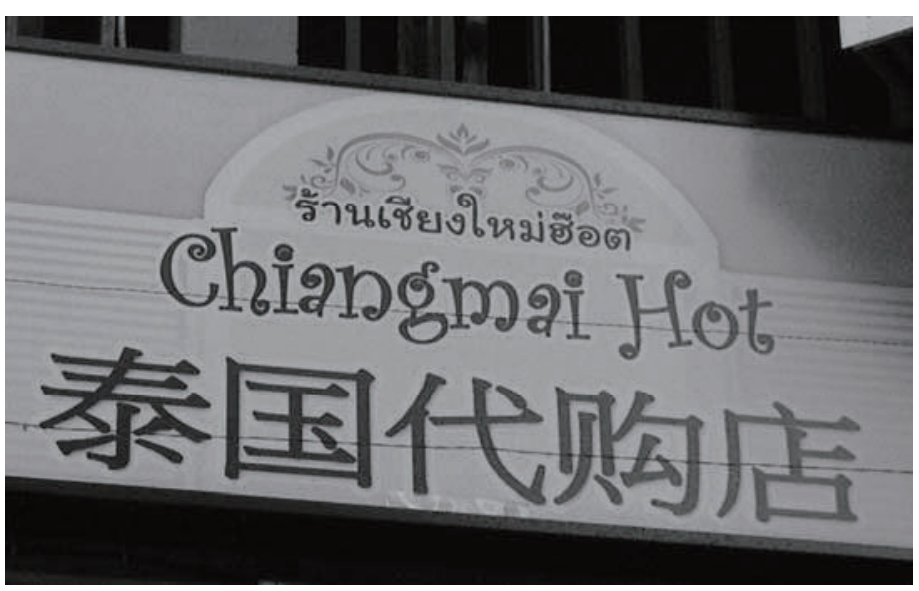

Picture 2: A Multilingual Sign

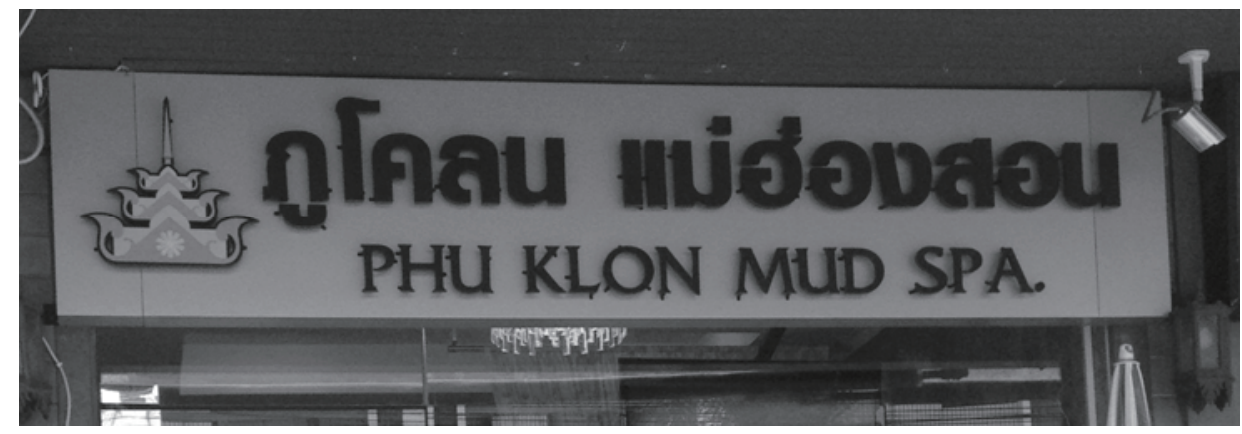

Picture 3: A Bilingual Sign 
but the word "shop" is missing in English translation. Thus the Thai-English portion of the sign might be classified as fragmentary indicating that the full information is given only in Thai and some piece of information is missing in English. In addition, the Chinese translation conveys a meaning that this is a shop selling products, but the Chinese equivalent of "Chiang Mai Hot" is missing. According to Reh (2004), the relationship between Chinese and the other two languages would be complementary as the Chinese version does not convey any information of "Chiang Mai Hot" compared to Thai and English scripts.

But even in bilingual signs, Rey's taxonomy often fails to account for the complex ways in which readers interpret the language mixing that occurs in typical multilingual environments. This can be illustrated by the Thai-English bilingual sign in picture 3. In the English line, Phu Klon refers to a well-known mud spa, and literally means "Mud Mountain". The Thai line, written in Thai script, reads "Phu Klon Maehongsorn", mentioning the adjacent province noted for mud baths and massages but not directly mentioning the type of business ("mud spa"). A surface analysis might lead one to conclude that this is an example of an overlapping arrangement of information, since both languages contain the common element, "Phu Klon", and each contains information not contained in the other: Thai mentions the name of the province; English mentions the type of business. But taking into account for cultural knowledge and inferences of the readers, it becomes clear that the amount of information extracted from the Thai portion of the sign is much greater than from the English side. Without specific mention of the business type, the Thai reader would infer it from the Thai "Phu Klon". Furthermore, addition of the province name adds an air of authenticity as the province noted throughout Thailand for its mud baths. It also triggers romanticized inferences of the rural north. Thus, the Thai version conveys much more information than the English, suggesting that this might best be analyzed as an example of fragmentary organization of information.

In a similar vein, attempts to employ commonly used metrics to determine language prominence (whether Kress and Van Leeuwen's notion of center-periphery, or the atheoretical top- bottom, or font size) often lead to conflicting conclusions. For example in the sign in picture 2, Thai might be considered prominent in its placement first, above the other two languages. But its prominence relative to the other two languages (and by implication the importance of its intended viewership) is mitigated by its smaller font size. English might be considered prominent due to its center location, but contains the least information. Judging by font size alone, Chinese could be considered the most prominent, aimed at the most important clientele. It might also be noted that as an overhead sign, Chinese, by virtue of is placement at the bottom on the sign, is closest to the pedestrian's line of gaze.

The point to be made here is that one cannot draw conclusions about the relative significance of the various languages on multilingual signs without taking into consideration multiple factors, among them the amount of information conveyed, the arrangement of that information on the sign, the types of font used, the placement of the sign in physical space relative to intended viewers, and the background knowledge and scripts the intended 
viewers bring to this tourist space. The paper next turns to an examination of the various linguistic, literary and rhetorical strategies and devices employed by shop owners in creating Nimmanhemin Road as a tourist destination.

\subsection{Strategies Employed}

Linguistic, literary and rhetorical strategies play a role in creating signs on Nimmanhemin Road to attract customers or tourists to visit a shop. These strategies can be described in terms of transliterations, homophones, blend words, acronyms, personifications, syntactic structures, speech acts and politeness strategies.

\subsubsection{Transliterations}

Transliteration is the visual transformation of words or phrases written in one language into the corresponding characters of another orthography. As shown in picture 4, a Thai shop's name can be represented in English orthography such as "E-PA SHABU" (อีปีา-ชาบู). In addition, to name a shop by using English, English sounds are transliterated in Thai orthography in "เลิฟเลิฟคิดส์" (Love Love Kids). A sign initiator may use transliteration from Thai to English in order for foreign tourists to know the Thai shop name. Alternatively, when a shop is named by using English words, the shop name appears to represent modernity and to attract all kinds of tourists.

\subsubsection{Lexical Blends}

Some shop names are the result of word formation, the creation of a new word, or of blending. According to Fromkin (2007), blending is a type of word formation by joining parts of two or more older words such as brunch (breakfast+lunch), smog (smoke + fog), etc. Using blend words makes shop names unique and gives general information to customers about products sold. For example, the shop name "Fruiturday" (see picture 6) is derived from "fruit" and "Saturday". It can imply that any day is a good day to enjoy fruit. Interestingly, blend words were not found in Thai, raising the question as to why English seems to be more susceptible to the creation of blends.

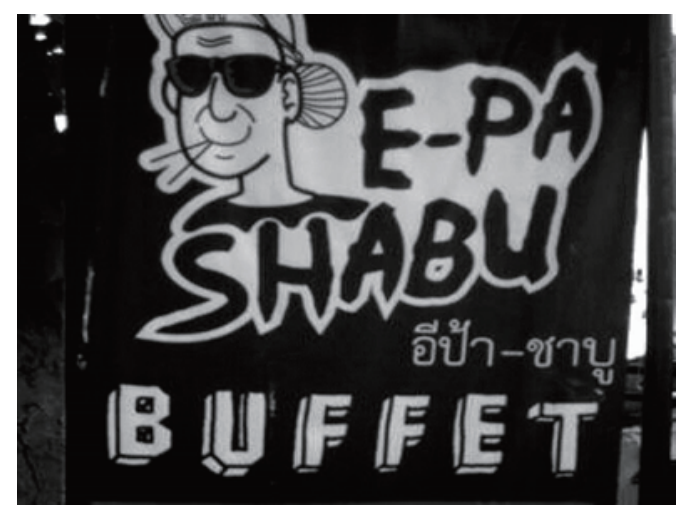

Picture 4: An Example of Transliteration

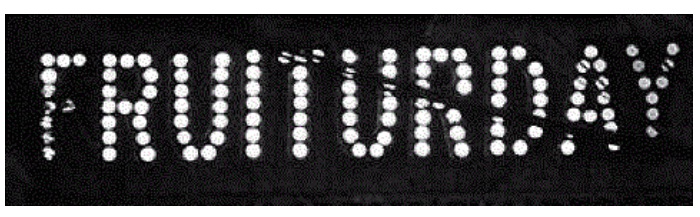

Picture 6: An Example of Blend

\subsubsection{Hybrid Syntactic Structures}

This kind of syntactic blending that results in a kind of hybrid language (Huebner 2006, 2009) was also found in the shop names of Nimmanhaemmin Road. To illustrate, the company name "บริษัท วี.เค.ที" (company V.K.T.) displays Thai lexicon and Thai syntax, where the Thai head noun for "company" (“บริษัท") precedes the modifier ("วี.เค.ที"), But at another level of 
analysis, the embedded noun phrase "วี.เค.ที เอ็นเตอร์เทนเมนต์" (V.K.T. entertainment) is English lexicon and syntax with the modifier preceding the head noun, transliterated into Thai and embedded in Thai syntax. The result is a kind of hybrid language combining both English and Thai syntax and lexicon, written in Thai script.

\subsubsection{Acronyms}

Some shops are named by using acronyms, words derived from the initials of several words (Fromkin, 2007). For example, as shown in picture 7, the shop named "HOB" is referred to "House of Beauty". Furthermore, it is found that acronyms or abbreviations are used in English but written in Thai. To illustrate, there is one sign written วี. เค. ที. or V.K.T. which represents the first name and the family name of the owner of the shop. How potential Thai readers interpret this and other English acronyms transliterated into Thai is a question beyond the scope of this study, but one worthy of future investigation.

\subsubsection{Homophones}

The use of homophones, two words pronounced the same but differing in meaning and perhaps spelling is also found. The sign "Long massage" (picture 5 ) is an example of a homophone. The word "long" is pronounced the same in all three languages, Thai, Chinese and English, but conveys different meanings in each. In English the word "long" means an extended period of time and appeals to the potential customers' desire to get their money's worth from the massage. In Chinese the word "long" refers to prosperity, a name often found in the names of Chinese businesses (see $\mathrm{Wu}$ and
Techasan, this volume). In Thai the word "long" means "to try experiencing new things."

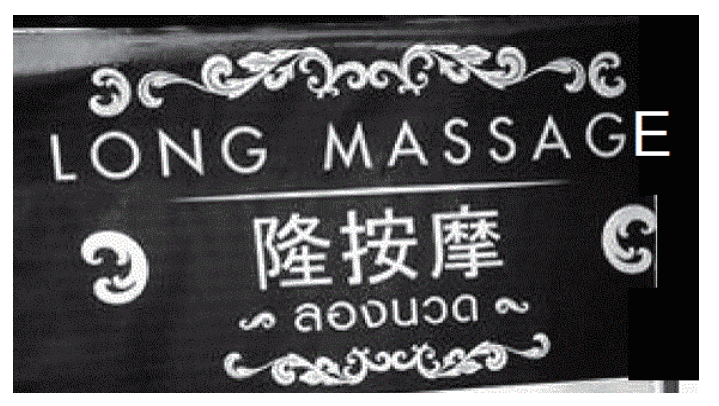

Picture 5: An Example of Homophone

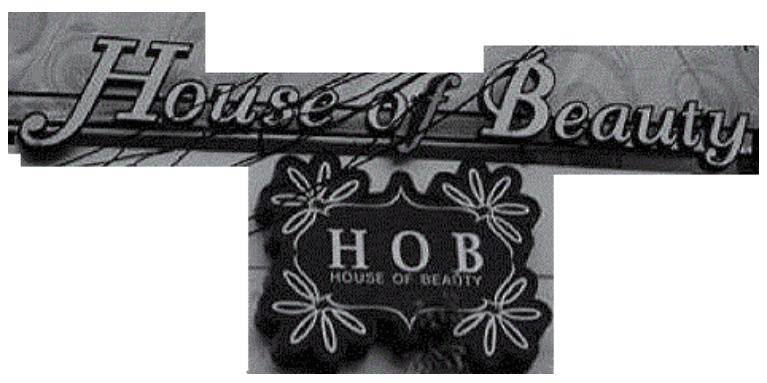

Picture 7: An Example of Acronym

\subsubsection{Personifications}

Some shop names display the usage of personification which is a figure of speech in which a thing, an idea or an animal is given human attributes. The non-human objects are portrayed in such a way that people feel they have the ability to act like human beings. From picture 8, the bookstore "Happy Books" indicates that books are feeling happy. Another bookstore named “ร้านเล่" (picture 9; literally "story-telling store") conveys the meaning that the bookstore is telling people stories. 


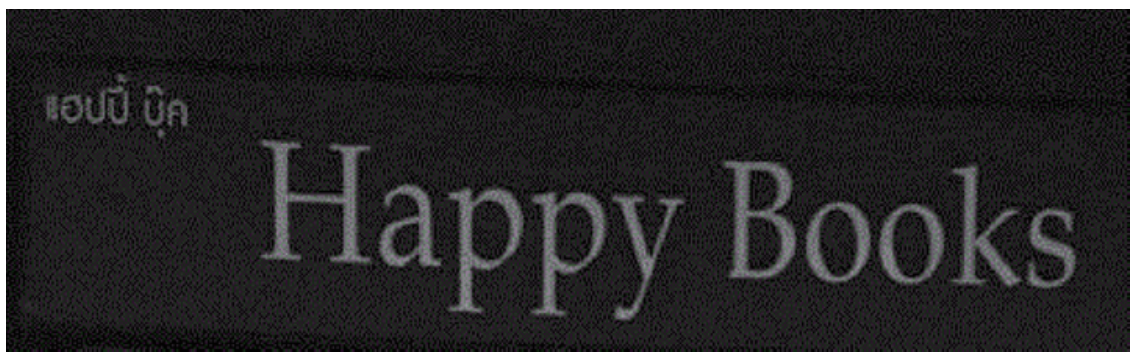

Picture 8: An Example of Personification

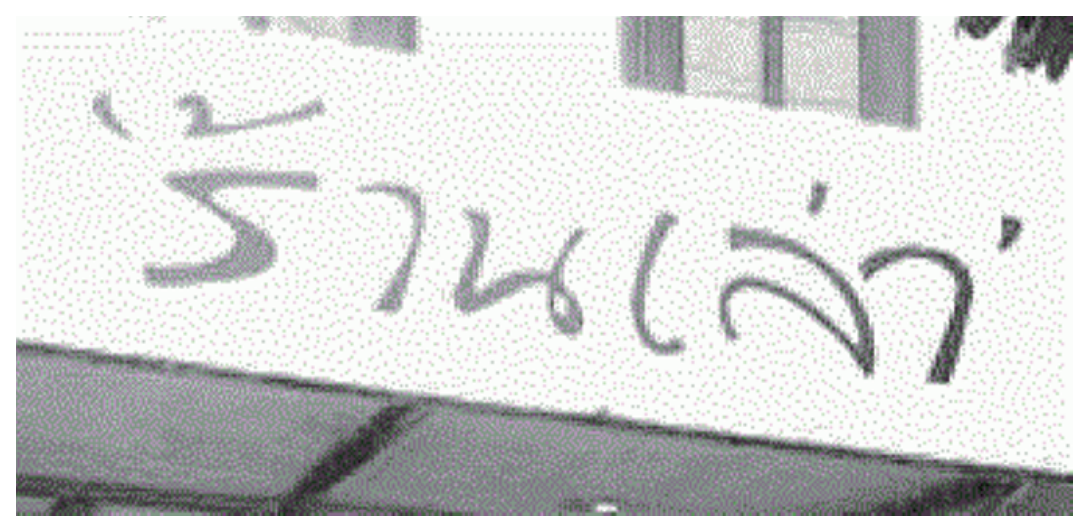

Picture 9: An Example of Personification

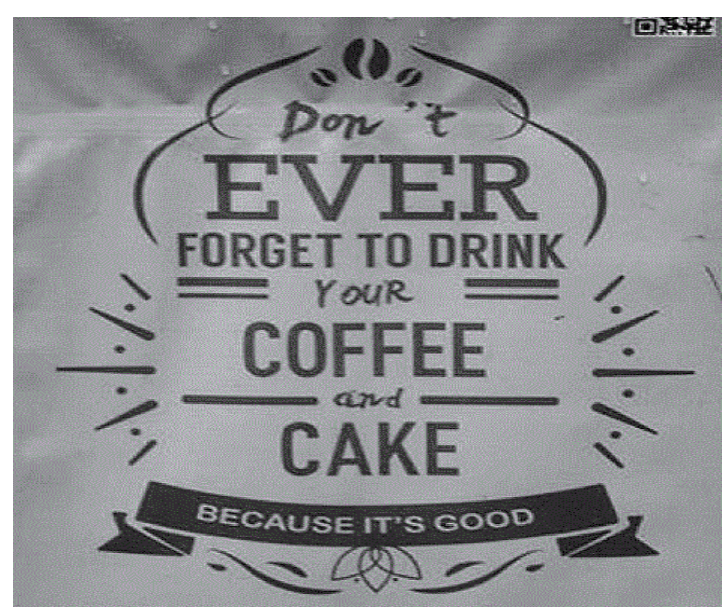

Picture 10: An Example of Speech Acts

\subsubsection{Speech Acts}

Shop signage can be discussed in terms of speech acts or acts that a speaker performs when making an utterance. For example,
"Don't ever forget to drink your coffee and cake because it's good" (as shown in picture 10) can be interpreted as a reminder which implies that if you do not want to miss tasty coffee and cake, you 
should buy coffee and cake here. In addition, the sign maker engages the reader/ viewer directly by using an imperative "Don't ever forget..." Another type of speech act that can be found from shop signage is a request. One sign written in Thai shows the message "ขอความ กรุณาเว้นพื้นที่ให้รถส่งของด้วย ขอบคุณค่ะ”, which means "Please leave some space for a delivery truck. Thank you". The sign consists of a speech act of request followed by a move of expression of gratitude. While it is written in Thai and therefore not intended for non-Thai tourists, and ends by using a speech act of thanking, a kind of negative politeness strategy, the sign maker may intend to model for Thais the kind of behavior that one should extend to tourists. This is an empirical question that could be addressed in another, qualitative follow-up study.

\subsubsection{Politeness Strategies}

Politeness strategies are not limited to Thai readers, but may also be directed toward foreign tourists. Brown and Levinson (1987) point out that as social beings we want to preserve what they call "positive face," or the desire to present a positive image to others, and "negative face," the desire not to be imposed upon. They further state that speech act can threaten the face of those who are being addressed. They refer to these as "Face Threatening Acts (FTAs)". They suggest five ways to act that may threaten the face of those we are addressing: (1) "Do the FTA baldly with no redressive action" (i.e. non-mitigating strategies can be used when a speaker prefers to do the FTAs with maximum efficiency rather than want to satisfy hearer's face), (2) "Do the FTA with redressive action with positive politeness strategies" (i.e. strategies selected when a speaker aims to please the addressee's desire to be liked), (3) "Do the FTA with redressive action with negative politeness strategy" (i.e. strategies chosen when a speaker aims to please the addressee's desire not to be imposed on), (4) "Go off-record" (i.e. strategies that are not directly produced. They have potential to convey more than one illocutionary acts) and (5) "Don't do the FTA." (i.e. non-performance of any kinds of linguistic realizations). Politeness strategies are intended to preserve the interlocutor's positive face and to mitigate the possible effects of negative face threatening acts.

These politeness strategies are also used in shop signage. Some shop signs convey direct and precise meaning concerning baldly on record. For instance, "Eat me" (picture 11) represents one literal meaning to attract people to eat food at this restaurant. Another example of a negative politeness strategy used in a shop sign can be seen in picture 12, which reads in part, "[You are] welcome to the grand opening." It attempts to address the reader's desire not to be imposed upon with the word 'เชิญ' ('to invite" here meaning 'welcome'), indicating in Thai that sign readers are not forced or imposed on, but they have options to visit the shop. Positive politeness strategies are found in signs representing attempts to satisfy the reader's desire to be liked or accepted. A smiling iconic expression (picture 13) is considered positive politeness strategy as this shop owner desires to be accepted by customers and wants a lot of customers coming to his or her shop. Using positive politeness strategies is a way of attracting customers. 


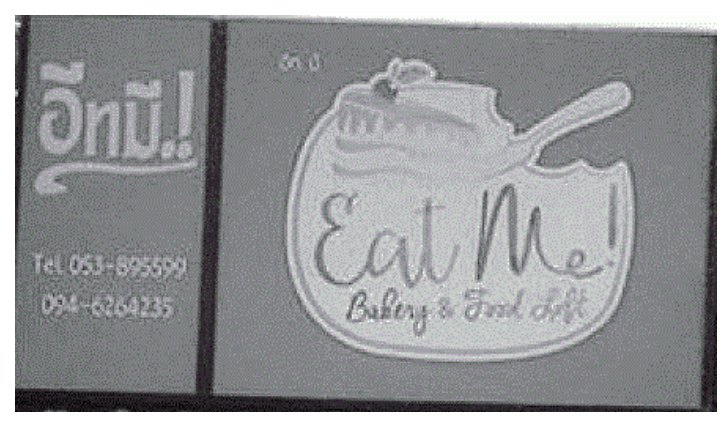

Picture 11: Politeness Strategy Used in Signage

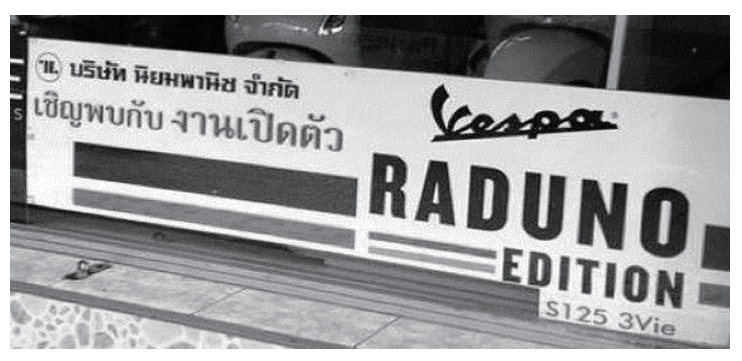

Picture 12: Politeness Strategy Used in Signage

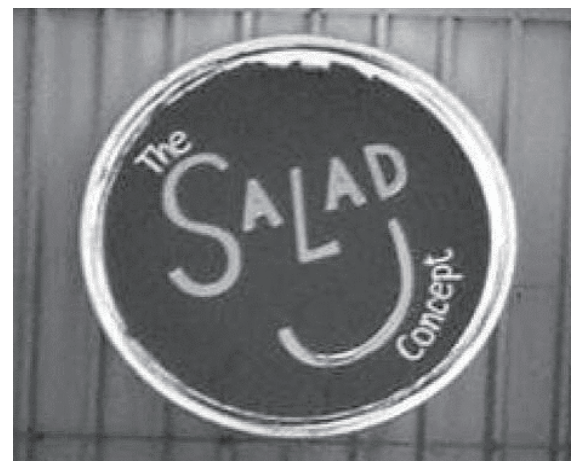

Picture 13: Politeness Strategy Used in Signage

\section{Discussion}

Palmer (1999) has pointed out that tourism can be conceptualized as a means of creating a positive national identity for foreign consumption. Along Nimmanhemin Road, the proliferation of massage parlors, spas and textile and souvenir shops and other services presents a commodification of traditional Thai culture for both domestic and international tourist consumption. The use of multilingual signs performs not only an informational function for readers of Thai, English or Chinese, the inclusion of the language or languages not accessible to a given reader adds an air of both authenticity and globalism to Nimmanhemin Road as an international tourist destination. Linguistic, literary and rhetorical strategies are also beneficial tools in the creation of signs to attract tourists. They catch the eye, engage the reader and occasionally elicit a smile.

A study of linguistic landscapes can provide some pedagogical applications for foreign language instruction. Language choices including English and Chinese appearing in public spaces hold much potential to develop students' foreign language knowledge. When linguistic landscape is used as a teaching resource, students can have awareness of the role that different languages play in the social communication network of their community (Sayer 2010). The use of linguistic landscape as a resource in teaching recognizes language use, and offers educators many opportunities to create meaningful experiences for learners. In addition, linguistic landscape can be considered as an educational tool which engages students in authentic activities that extend beyond the classroom and thereby link learners' life in school to their community existence. If educators use authentic signs to integrate content in the school curriculum, students might find learning resources in foreign languages more motivating and engaging, since linguistic landscapes reflect authentic language use in diverse ways that are familiar to students (Bradshaw 2014). The fact that texts in landscape are visible does 
not mean that students always see them, pay attention to them, read them, or understand how they work. To raise language awareness by letting students be exposed to authentic contexts in foreign languages can make them conscious of linguistic strategies of their landscape that they may have previously taken for granted. An important part of the process is a pedagogical approach that allows students to recognize public space as an arena in which different players, such as advertisers and business persons, exercise influence in ways that are often hidden or covert such as the use of speech acts or politeness strategies. Linguistic landscapes are therefore useful to develop students' critical thinking skill as well as their pragmatic competence, so that they are able to read between lines in authentic contexts.

\section{References}

Abousnnouga, G. \& Machin, D. (2010). Analysing the language of war monument: Sage Publications. Los Angeles, London, New Delhi, Singapore and Washington DC. Reprints and permissions: http://www.sagepub.co.uk/journal spermissions.nav/ Vol 9(2): 131149 DOI $10.1177 / 1470357210369884$.

Backhaus, P. (2006). Linguistic landscapes: A comparative study of urban multilingualism in Tokyo. Clevedon; Buffalo: Multilingual Matters.

Bradshaw, I. (2014). Linguistic Landscape as a language learning and Literacy Resources in Caribbean Creole Contexts. Caribbean Curriculum Vol 22: 157-173.
Bruyei- Olmedo, A. \& Juan-Garau, M. (2009). English as a lingua franca in the linguistic landscape of the multilingual resort of S'Arenal in Mallorca. International Journal of Multilingualism 6(4). 386-411.

Bolton, K. (2012). World Englishes and linguistic landscapes. World

Englishes, 31(1), 30-33. doi:10.1111/j.1467-971X.2011.01748.x

Boudreau, A. and White, C. (2004). Turning the tide in Acadian Nova Scotia: how heritage tourism is changing language practices and representations of language.

Canadian Journal of Linguistics, 49(3/4): 327-351.

Brown, P., \& Levinson, S. (1987). Politeness: Some Universals in Language Usage. Cambridge: Cambridge University Press.

Cenoz, J. \& Gorter, D. (2008). The linguistic landscape as an additional source of input in second language acquisition. International Review of Applied Linguistics in Language Teaching, 46(3), 267-287. doi:10.1515/IRAL.2008.012.

Cohen, E. \& Cooper, R.L. (1986). Language and tourism. Annals of Tourism Research, 13: 533- 563.

Coulmas, F. (2009). Linguistic Landscaping and the Seed of the Public Sphere. In Shahomy, E. \& Gorter, D. (eds).

Coupland, N., Garrett, P. and Bishop, H. (2005). Wales underground: discursive frames and authenticities in Welsh mining heritage tourism 
events. In Discourse, Communication and Tourism, A. Jaworski and A. Pritchard (eds), pp. 199-222. Clevedon: Channel View Publications.

Cos, J.P. (2006). Language, Culture and Tourism: Perspectives in Barcelona and Catalonia. Barcelona:

Turisme de Barcelona.

Dagenais, D., Moore, D., Sabatier, C., Lamarre, P. \& Armand, F. (2009).

Linguistic Landscapes and

Language Awareness. In E. ShohamyC. \& D. Gorter (Eds.), Linguistic Landscape:

Expanding the Scenery (pp. 253269). New York, NY: Routledge.

Dray, S. (2010). Ideological struggles on signage in Jamaica. In A. Jaworski \& C. Thur-low (Eds.), Semiotic landscapes: Language, image, space (pp. 102-122). London, UK:

Continuum.

Draper, J. (2010). Inferring ethnolinguistic vitality in a community of Northeast Thailand. Journal of Multilingual \& Multicultural Development, 31(2), 135- 147.

Drozdzewski, D. (2011). Language tourism in Poland. Tourism Geographies, 13(2): 165-186.

Dressler, R. (2015). Signgeist: promoting bilingualism through the linguistic landscape of school signage. International Journal of Multilingualism, 12:1, 128-145.

Fromkin, V. (2007). An Introduction to language. Cengage Learning: Wadsworth, Boston.
Gorter, D. \& Cenoz, J. (2006). Linguistic landscape and minority languages, International Journal of Multilingualism (special issue), 3 (1), (67-80). http://dx.doi.org/10. 1080/14790710608668386

Hanauer, D. I. (2009). Science and the linguistic landscape: A genre analysis of representational wall space in a microbiology laboratory. In E. Shohamy \& D. Gorter (eds.) Linguistic Landscape: Expanding the Scenery. New York \& London: Routledge. 287-301.

Hatfield, Leerabhandh, S. (2005). Lexical variation of Chiang Mai dialect in Chiang Mai Province, Thailand. Ph.D| dissertation. University of Georgia.

Heller, M. (2003) Globalization, the new economy and the commodification of language. Journal of Sociolinguistics 7 (4), 473492.

Huebner, T. (2006). Bankok's linguistic landscapes: Environmental print, codemixing and language change, International Journal of multilingualism, 3 (1): 30-57.

Huebner, T. (2009). A Framework for the Linguistic Analysis of Linguistic Landscapes. In E. Shohamy and D. Gorter (eds) Linguistic Landscape: Expanding the Scenery (pp. 70-87). New York: Routledge.

Ivković, D., \& Lotherington, H. (2009). Multilingualism in cyberspace: Conceptualising the virtual linguistic landscape. International Journal of Multilingualism, 6(1), 17-36. 
Jaworski, A. (2010). Linguistic landscapes on postcards: Tourist mediation and the sociolinguistic communities of contact. Sociolinguistic Studies 4/3. 469-594.

Jaworski, A. \& Yeung, S. (2010). Life in the Garden of Eden: the naming and imagery of residential Hong Kong. In Shohamy, E., Ben-Rafael, E. \& Barni, M. (eds.). Linguistic Landscape in the city (pp. 153-181). Bristol: Multilingual Matters.

Jones, R.H. (2011). Creativity and discourse. World Englishes, 29(4), 467480 .

Kallen, J. (2009). Tourism and Representation in the Irish Linguistic Landscape. In E. Shohamy and D. Gorter (eds) Linguistic Landscape: Expanding the Scenery (pp. 270-283). New York: Routledge.

Landry, R. \& Bourhis, R. Y. (1997) Linguistic landscape and ethnolinguistic vitality: an empirical study. Journal of Language and Social Psychology 16 (1): 23-49.

Lock, G. (2003). Being international, local and Chinese: advertisements on the Hong Kong Mass Transit Railway. Visual Communication, 2 (2), 195-214.

Lou, J. J. (2010). Chinese on the Side: The Marginalization of Chinese in the Linguistic and Social Landscapes of Chinatown in Washington, DC. In E. Shohamy, E. Ben-Rafael and M. Barni (eds) Linguistic Landscape in the City (pp. 96-113). Bristol, Buffalo, Toronto: Multilingual Matters.
Manca, E. (2008). From phraseology to culture: qualifying adjectives in the language of tourism. International Journal of Corpus Linguistics, 13(3): 368-385.

Marten, H. F. (2010). Linguistic Landscape under Strict State Language Policy: Reversing the Soviet Legacy in a Regional Centre in Latvia. In E. Shohamy, E. Ben-Rafael \& M. Barni (Eds.), Linguistic Landscape in the City (pp. 115-132). UK: MPG Books Group.

Moriarty, M. (2015). Indexing authenticity: The linguistic landscape of an Irish Tourist Town. International Journal of the Sociology of Language 232 (2015), 195-214. DOI: 10.1515/ijsl-2014-0049.

Palmer, C. (1999). Tourism and the symbols of identity. Tourism Management, 20, 313-321.

Piller, I. (2010). Sex in the city: On making space and identity in travel spaces. In Adam Jaworski \& Crispin Thurlow (eds.), Semiotic landscapes: Language, image, space, 123-136. London: Continuum.

Pietikäinen, S. and Kelly-Holmes, H. (2011). The local political economy of languages in a Sámi tourism destination: authenticity and mobility in the labelling of souvenirs. Journal of Sociolinguistics, 15(3): 323-346.

Ploner, J. (2013). Narrating regional identity in tourism - sketches from the Austrian Danube valley. Language and Intercultural Communication, 9(1): 214. 
Rey, M. (2004), Multilingual writing: a reader-oriented typology with examples from Lira Municipality (Uganda), International Journal of the Sociology of Language, 40:126.

Sayer, P. (2010). Using the linguistic landscape as a pedagogical resource. English Language Teaching Journal, 64(2), 143-154. doi:10.1093/elt/ccp051.

Salim, A. et al. (2012). Language for tourism: a Literature review. Social and Behavioral Sciences 66, 136 143.

Staiff, R. (2011). Is tourism killing heritage places? Case-study Venice. Conference Paper. Geography Teachers Association of NSW. HSC Extension Study Program, University of Western Sydney: Sydney.

Shohamy. E., \& Waksman, S. (2009). Linguistic landscape as an ecological arena: Modalities, meanings, negotiations, education. In E. Shohamy \& D. Gorter (Eds.), Linguistic landscape: Expanding the scenery (pp. 313-331). London, UK: Routledge.

Sloboda, M. (2009). State ideology and linguistic landscape: A comparative analysis of (post)communistBelarus, CzechRepublic, and Slovakia. Elana Shohamy and Durk Gorter, eds. Linguistic landscape: Expanding the scenery. New York: Routledge, 17388.

Strand, T. (2012). Winning the dialect popularity contest: mass-mediated language ideologies and local responses in rural Valdres, Norway.
Journal of Linguistic Anthropology, 22(1): 23-43.

Strand, T. (2013). Dialect Meta-Register and Popular Linguistic Awareness in Heritage Marketing and Tourism. Paper presented at the Locating Language: A Symposium on the Linguistics of Place, The Ohio State University, Columbus, $\mathrm{OH}$, April 22.

Thurlow, C. \& Jaworski, A. (2011). Banal globalization? Embodied actions and mediated practices in tourists' online photo-sharing. In Crispin Thurlow and Kristine Mroczek (eds), Digital Discourse: Language in the New Media, 220-250. New York: Oxford University Press.

Troyer, R. (2012). English in the Thai linguistic netscape. World Englishes 31(1). 93-112.

Trumper-Hecht, N. (2009). Constructing national identity in mixed cities in Israel: Arabic on signs in the public space of upper Nazareth. In D. Gorter \& E. Shohamy (Eds.), Linguistic landscape: Expanding the scenery. New York: Routledge.

Ward, H. (2012). Language goes deepen, TES Magazine. 